\title{
Crop growth and development affect seasonal priorities for lucerne management
}

\author{
D.J. MOOT, H.E. BROWN, E.I. TEIXEIRA and K.M. POLLOCK \\ Soils, Plant and Ecological Sciences Division, P.O. Box 84, Lincoln University, Canterbury \\ moot@lincoln.ac.nz
}

\begin{abstract}
Successful lucerne stand management requires balancing animal and plant requirements to produce crops of high quality and yield at times of high animal demand. Understanding the impact of environmental signals on crop growth and development can aid management decisions throughout the season. In spring, crops remobilise reserves from the roots to shoots and expand nodes accumulated through the winter, producing rapid stem extension and canopy closure as temperatures increase. The timing of spring defoliation should be based on crop yield and animal requirements rather than any specific developmental stage. Through spring and summer, crops should be rotationally grazed, with highest lamb live-weights achieved from 6-8 weeks grazing solely on lucerne. Summer crop production is dependent on rainfall and the plant available water content. During summer, grazing at the appearance of open flowers or basal buds is recommended as a compromise between maximum yield and quality. In autumn, the priority of assimilates allocation in the crop changes from above to below ground growth. To enhance the recharge of root reserves, an extended period of flowering is recommended in February or March. The time of flowering is dependent on the accumulation of thermal time and increases as photoperiod shortens. In periods of prolonged drought, lucerne herbage should be hard grazed and then spelled until the end of late autumn regrowth. A final hard grazing in June or early July, to remove overwintering aphids, should be followed by spraying 7-14 days later. Crops continue to develop nodes through the winter, and stands should be spelled until spring to ensure nodes are not removed by grazing, as this delays regrowth and reduces dry matter production.
\end{abstract}

Key words: Flowering, grazing, herbicide, Medicago sativa, nodes, photoperiod, phyllochron, root reserves

\section{Introduction}

Lucerne (Medicago sativa) has been promoted in New Zealand as the most suitable forage species for intensive dryland sheep production systems for over 100 years (Langer 1967; Wynn-Williams 1982). Despite the plethora of research and extension work advocating its inclusion in these systems, the area of lucerne grown has declined since the 1970s (Purves \& Wynn-Williams 1989). Recent data on seed sales show a continued downward trend (Rolston 2003). However, interest remains due to recent droughts and predictions of greater rainfall variability in traditional lucerne-growing areas of the east coast of New Zealand (Salinger 2003). In addition, pest and disease problems that plagued lucerne crops in the 1980 s were overcome by the introduction of new resistent cultivars (Purves \& Wynn-Williams 1989). Surprisingly, 'Wairau', which is highly susceptible to most lucerne pests, is still the most commonly sown cultivar (Kirsopp 2001).

A recent survey of dryland farmers in the South Island showed that lucerne was grown on $67 \%$ of properties, but averaged less than $20 \%$ of the farm area (Kirsopp 2001). This compares with recommendations for 40 $60 \%$ of the farm to be in lucerne to maximise lamb live-weight gains (White 1982). This contrast suggests the integration of lucerne into farm systems has not been completely successful. A reason for this could be the sometimes-conflicting aims of lucerne and animal objectives, and particularly a perceived inflexibility of lucerne management at times of high feed demand in spring. For example, of the farms surveyed, lambing percentage (survival to tailing) was $15 \%$ higher for farms with lucerne, but the mean lambing date (6 September) was 3 weeks later than on farms with no lucerne. This later date may restrict late spring and summer animal and plant growth, particularly in dry areas.

Thus, to increase the proportion of lucerne on farms requires consideration of animal, plant and management objectives. In this paper, animal production is discussed based on previous research results and interpreted as a requirement for the provision of high yield and quality lucerne at times of high animal demand, notably spring and summer. For crop performance, lucerne productivity is 
considered, including minimising weed ingress and understanding seasonal changes in root carbohydrate and protein supply to enhance stand longevity. Recommendations for seasonal grazing management, in relation to these sometimes conflicting animal and plant goals, are presented with the aim of maximising the flexibility of lucerne stand management.

Difficulties in this approach include the wide geographic distribution over which lucerne is grown and the diversity of roles that lucerne has on farms, which lead to varied farm management objectives. Therefore, to broaden the scope of the recommendations, crop growth and development are initially described. Response to environmental signals are then used to explain seasonally based objectives for crop and animal management. We also discuss how irrigation may be used to complement objectives, but no other agronomic factors are discussed. Data for this paper were drawn from several published sources, but where data are presented from previously unpublished work, brief experimental details are given.

\section{Lucerne growth and development}

Knowledge of the growth and development of lucerne stands both within a regrowth cycle and across seasons is fundamental to understand recommendations for lucerne management. Growth refers to the accumulation of dry matter (DM) as the result of light interception and partitioning of the products of photosynthesis. Development is the 'age' or maturity of the regrowth crop within a cycle (Christian 1977). Development stages describe changes on stems, such as expansion of vegetative nodes, flower bud initiation and flower opening (Kalu \& Fick 1981). Lucerne growth and development are strongly linked and altered by environmental signals across seasons.

Vegetative growth and development are based on the production of new nodes and attached leaves, on the apices or growing points, at the top of each stem (Fick et al. 1988). Regrowth, after defoliation by grazing or cutting, occurs from new basal buds located on the crown of the plant (Thomas 2003). Basal buds initiation and early growth are driven by remobilisation of carbohydrate and amino acid reserves from stores in the crown and tap root (Avice et al. 1996). The first leaves produced on the lower nodes are small, so initially light interception and the subsequent increase in DM are low. This lag phase (in regrowth crops) is shortest under high temperatures that promote rapid leaf production and leaf expansion (Fick et al. 1988). When light interception has increased to critical levels, growth rates become linear and are related to temperature and water supply (Brown et al. 2003). During the linear growth period, development usually changes from vegetative leaf and node production to bud initiation and flowering. The transition to reproductive development results in a reduction in shoot DM accumulation and an increase in crown and tap root reserves (Heichel et al. 1988). These reserves are utilised to produce basal buds for the following regrowth cycle (Ta et al. 1990).

\section{Seasonal growth and development}

The pattern of lucerne growth and development within each regrowth cycle shows seasonal variation. Specifically, shoot growth rates increase with increased temperature, but are higher in spring than in autumn at the same temperature (Figure 1). This difference is caused by seasonal changes in the allocation of DM production between shoots and roots (Khaiti \& Lemaire 1992). In spring, roots lose weight as stored carbohydrates are either lost in respiration and remobilised for the initiation of the new basal buds after defoliation (Kim et al. 1993). In contrast, autumn shoot growth is reduced because of increased assimilate partitioning to roots as plants replenish reserves for overwintering and spring regrowth (Hendershot \& Volenec 1992; Kim et al. 1991).

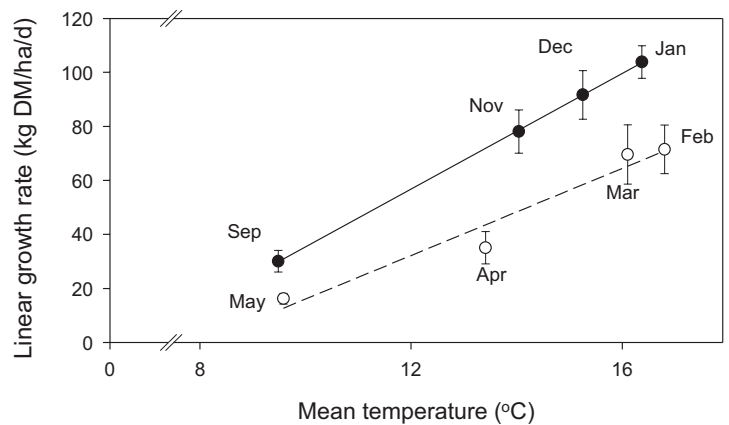

Figure 1 Linear growth rates of irrigated lucerne in relation to mean temperature at Lincoln University, Canterbury, New Zealand. Each point represents the mean from 5 years data and bars represent one standard error either side of the mean. Linear regressions fitted to data from September-January $(\bullet, y=-71.5+10.7 x$, $\left.\mathrm{R}^{2}=0.99\right)$ and February-May $(\mathrm{O}, \mathrm{y}=$ $\left.64.7+8.0 x, R^{2}=0.92\right)$. Adapted from (Brown et al. 2000). 
The change in root DM for a 3-year-old 'Kaituna' lucerne stand grown at Lincoln University in 20022003 is shown in Figure 2. Root samples were harvested from $0.2 \mathrm{~m}^{2}$ quadrats to a depth of $0.3 \mathrm{~m}$ for each of three replicates at 7-10 day intervals. Crops were managed in common for the first 2 years, but two different grazing treatments were imposed in the third year to demonstrate their effect on DM production. The 28-day (short) or 42-day (long) rotations commenced on 1 September 2002 and were consistent throughout the remainder of the season. These rotations included 3-4 days grazing to remove all herbage. Any residual stem was trimmed postgrazing to ensure only new aboveground growth was measured.

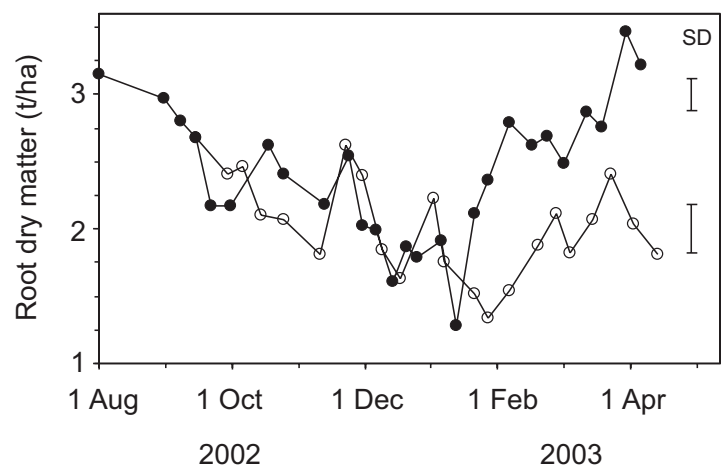

Figure 2 Root dry matter of irrigated 'Kaituna' lucerne crops defoliated at 28-day $(\mathrm{O})$ or 42-day (•) intervals at Lincoln University, Canterbury, New Zealand.

For both treatments, there was a net loss of root DM in spring and summer regardless of rotation length (Figure 2). For example, the 42-day rotation treatment showed minimal changes in partitioning of assimilates to replenish the root reserves prior to the longest day in mid-summer. In autumn, the short-rotation (28day) crop continued to lose root DM as stored root reserves were used to renew the canopy of stems at the beginning of each regrowth cycle. In contrast, the long-rotation crop replenished root reserves throughout February and March to at least $3 \mathrm{t} / \mathrm{ha}$, which was similar to the level measured at the beginning of the previous spring 2002. The difference in underground root reserves between the two crops influenced shoot DM production the following spring (Figure 3). The long-rotation crops produced twice the DM of the short-rotation crops by mid-September despite experiencing the same winter and early spring conditions (Figure 3).

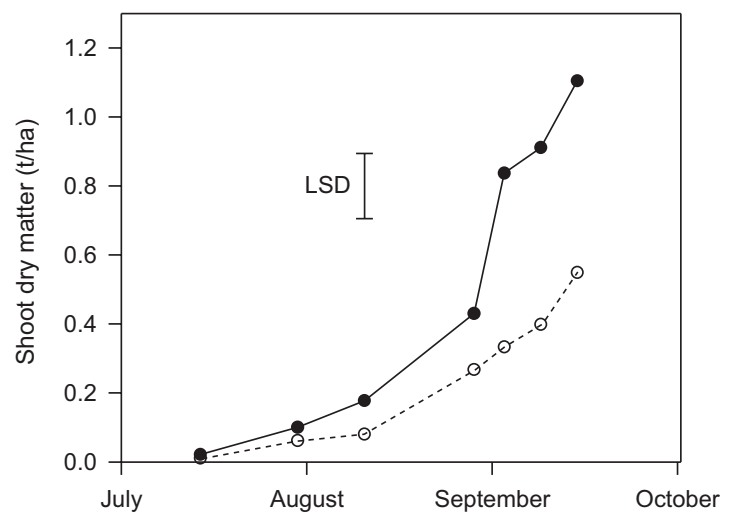

Figure 3 Early spring dry matter accumulation following 28-day $(O)$ or 42-day $(\bullet)$ defoliation intervals during the previous year at Lincoln University, Canterbury, New Zealand.

Vegetative and reproductive development also exhibits seasonal trends. The rate of vegetative node appearance increases in spring (Moot et al. 2001). This is due to increased temperatures, which accelerate the accumulation of thermal time (the sum of daily mean temperature). Brown (unpubl. data) has shown that the thermal time interval between successive nodes (phyllochron) of 'Kaituna' lucerne was constant $\left(37 \pm 5^{\circ} \mathrm{Cd}\right)$ in winter, spring and summer. Thus, for a mean summer temperature of $17.5^{\circ} \mathrm{C}$, a node will appear every second day. In contrast, in winter, when mean temperatures are $4.5^{\circ} \mathrm{C}$ a node appears every 7-10 days, and leaf area expansion is slower. In autumn, phyllochrons may increase up to $60{ }^{\circ} \mathrm{Cd}$, reducing the rate of canopy expansion.

The time from defoliation to flowering is also dependant on thermal time (Moot et al. 2001). However, the amount of thermal time required for lucerne to reach flowering is modified by photoperiod requirements. Lucerne is a long day plant; therefore, the thermal time interval from defoliation to flowering increases as day-length decreases (Major et al. 1991). This is shown in Figure 4, where the accumulated thermal time required from defoliation to flowing increased from 380 to $550{ }^{\circ} \mathrm{Cd}$ as the mean photoperiod decreased from 16 to 13.5 hours (Moot et al. 2001).

In the remainder of this paper we will outline how these seasonal responses of lucerne growth and development can be used to develop seasonally based management objectives to maximise both animal and plant performance. 


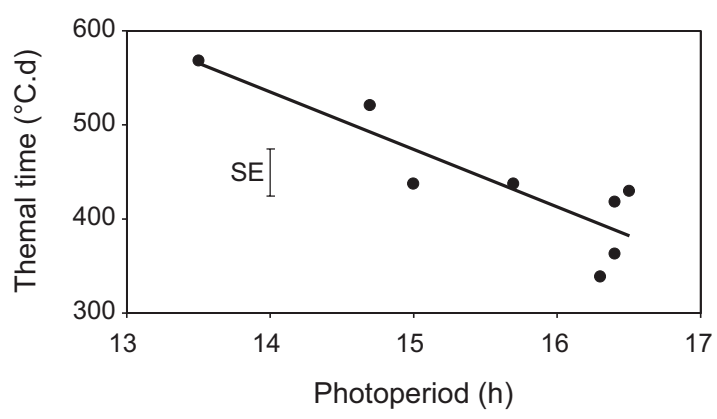

Figure 4 Thermal time requirement to reach bud initiation against mean photoperiod of irrigated 'Kaituna' lucerne crops grown at Lincoln University, Canterbury, New Zealand. From (Moot et al. 2001). Linear regression $y=1425-67.2 x, R^{2}=0.86$.

\section{Winter (June-August)}

Objectives for winter management should be related to weed control and ensuring that crop regrowth is as early and vigorous as possible in spring. Ideally, a 'clean-up' graze of any residual autumn herbage in late June/early July can be used to remove any overwintering aphids (Douglas 1986). This graze should be followed 7-10 days later by appropriate contact and residual activity herbicides. The crop should be spelled until spring defoliation. In practice, the timing of herbicide application may be delayed and/or regrowth may need to be defoliated in late winter or early spring.

The impact of late winter herbicide and early spring grazing on the subsequent timing, production and composition of 'Kaituna' lucerne was measured for a 4-year-old stand at the Lincoln University dryland research farm 'Ashley Dene' in 2002-2003. Six 25 m² $^{2}$ areas in an 8.1 ha paddock were fenced off after the final grazing in late May. This enabled us to make measurements from two replicates of three winter management treatments without interfering with other farm operations. Two of the $5 \times 5 \mathrm{~m}$ areas were left unsprayed and ungrazed as controls. Two others were sprayed with Paraquat and Atrazine at recommended rates on 31 July 2002. The remaining two areas were cut to ground level on 21 August to simulate the early-spring grazing that was occurring simultaneously within the main paddock. Weekly DM samples were measured from two $0.2 \mathrm{~m}^{2}$ quadrats per plot throughout the season. Botanical composition was determined from the final sample in each regrowth period when crops had produced $\sim 3-4 \mathrm{t} \mathrm{DM} / \mathrm{ha}$. At this stage, all herbage in the enclosure areas was cut to just above lucerne crown level to simulate hard grazing, and the residual herbage was removed from the treatment area.

For the ungrazed and unsprayed control crops, a linear growth rate of $70 \mathrm{~kg} \mathrm{DM} / \mathrm{ha} / \mathrm{d}$ from mid-August produced $2.8 \mathrm{t}$ lucerne $\mathrm{DM} / \mathrm{ha}$ by the first week of October (Figure 5). There was additional growth of $31 \%$ weeds-predominantly the annual weeds shepherd's purse (Capsella bursa-pastoris) and storksbill (Erodium cicutarium). The sprayed crop had a similar linear growth rate to the control, but this commenced 14 days later. By the first week of October, the sprayed crops were weed-free and yielded $2.4 \mathrm{t}$ $\mathrm{DM} / \mathrm{ha}$ and had increased to $2.8 \mathrm{t} \mathrm{DM} / \mathrm{ha}$ at the final harvest 2 weeks later.

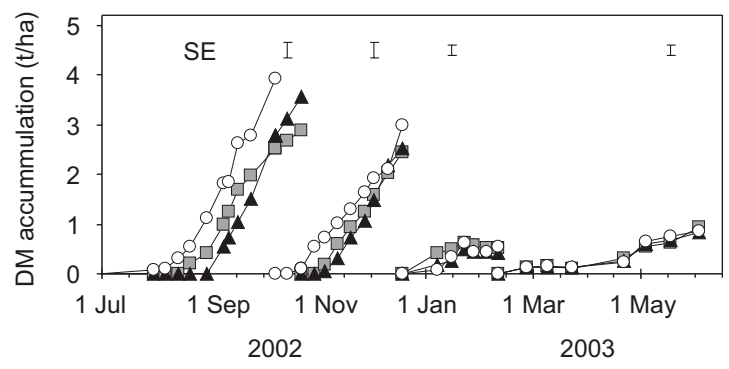

Figure 5 Dry matter (DM) accumulation over time for winter sprayed $(O)$, grazed $(\boldsymbol{\Delta})$ or ungrazed $(\square)$ dryland lucerne crops grown at Ashley Dene, Canterbury, New Zealand.

For the August-grazed crop, linear growth in spring did not commence until early September, and the final spring lucerne yield was $1.9 \mathrm{t} \mathrm{DM} /$ ha in mid-October, with a further $1.7 \mathrm{t} /$ ha of weeds. Subsequent production was similar to the sprayed treatment, and all three crops were weed-free.

These results indicate that the 31 July herbicide application date was too late to avoid damage to the developing lucerne buds. Furthermore, the late-winter (21 August) grazing decreased the final lucerne yield by $25 \%$ because grazing removed the growing points from each stem. New stems had to be initiated, which delayed spring grazing by 4 weeks and enabled weed content to increase to $50 \%$. The weeds were also more mature than in the ungrazed treatments, and were likely to have been included in any conserved forage.

Differences in the early-spring DM production caused 
by the winter herbicide and grazing treatments can be explained in relation to crop development. The relationship between the number of vegetative nodes on a stem and crop height has been examined over several years for the first spring rotation of 'Kaituna' lucerne crops grown at Lincoln University and 'Ashley Dene'. An example of the results from Ashley Dene is shown in Figure 6. The number of nodes and plant height were measured from five tagged stems per plot in each of three replicates at 4-7 day intervals. By the beginning of August, when plants were only $20 \mathrm{~mm}$ high, there were already 4 nodes on the stem and the internode length was $0.5 \mathrm{~mm}$. Stems had developed 8-10 nodes by late August, when plants were $<100 \mathrm{~mm}$ high (thus the internode length was $\sim 10 \mathrm{~mm}$ ). From this time, the number of nodes continued to increase linearly, but plant height increased exponentially to give a mean internode of $30 \mathrm{~mm}$ by the time the crop had produced $3.7 \pm 0.16 \mathrm{t} \mathrm{DM} /$ ha in early October.

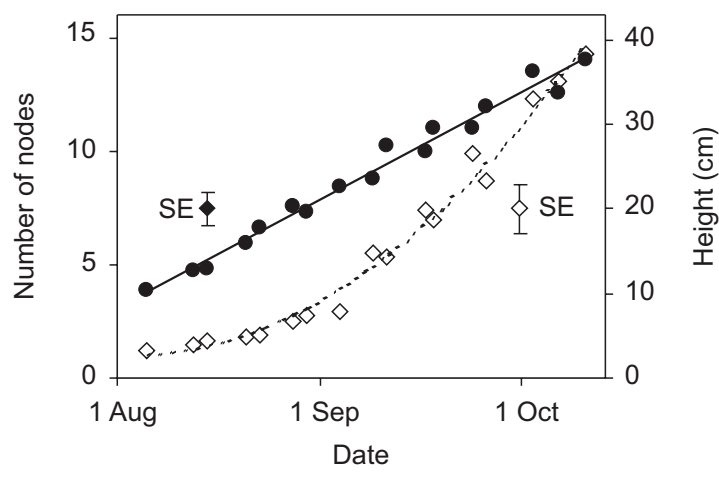

Figure 6 Spring node appearance $(\bullet)$ and stem height $(\diamond)$ of a lucerne crop grown at Ashley Dene, Canterbury, New Zealand in spring 2002. (Node number: $y=-1.999$ $+0.156 x, R^{2}=0.981$; Stem height: $y=$ $0.0080 x^{2}-0.553 x+12.35, R^{2}=0.986$. Based on days from 30 June 02 ).

The potential for rapid stem elongation, and consequently early spring DM production, resulted from vegetative node accumulation during winter. At that time, growth was minimal and stands had produced less than $400 \mathrm{~kg} \mathrm{DM} / \mathrm{ha}$. Thus, the small amount of available grazing removes the growing point, preventing rapid stem elongation and consequently leaf area expansion. This results in a delay in spring DM production as plants develop a completely new cohort of basal buds. Low temperatures during this time mean the accumulation of the $37^{\circ} \mathrm{Cd}$ required per node is slow, so the plant cannot compensate for early bud removal by producing subsequent nodes at a faster rate.

It follows that any management that removes the growing point of lucerne during the late-winter/earlyspring period will reduce the yield potential and has important and ongoing consequences for spring growth. Set-stocking of crops at any time results in the continual removal of these newly developing shoots. The resulting need for continuous development of new basal shoots by the plant causes a rapid depletion of root-reserves, as seen in the shortrotation treatment (Figure 2). Set-stocking also prevents the canopy from expanding and light interception is reduced. As a consequence, the ability of the stand to outcompete germinating spring annual weeds is compromised.

\section{Spring (September-November)}

In spring, the main objectives are usually to maximise live-weight gain of lambs grazing lucerne or maximize the yield and quality of stands for forage conservation. During spring, crop growth with increasing temperature (Figure 1), and solar radiation and water are usually non-limiting. Flowering is delayed by the short photoperiod (Figure 4), so defoliation should be based on crop growth rather than development criteria such as flowering or basal bud development.

For dryland systems, where lucerne makes up a high $(>30 \%)$ proportion of the farm cover, early spring grazing is inevitable. In these circumstances, grazing must commence in some paddocks before they reach their maximum DM yield. To minimise the impact on stand persistence, it is preferable to begin grazing in older stands that are targeted for renewal. Waiting until herbage is $25-30 \mathrm{~cm}$ high provides a compromise between maximising rapid stem extension (Figure 6) and meeting increasing animal demand. The duration of defoliation must then be set to avoid damaging these new stems, that encourages the subsequent regrowth of the crop. Ideally, ewes with lambs at foot should be rotationally grazed on these stands at a stocking-rate that enables all herbage to be removed within 7-10 days. Extending the grazing duration beyond 10 days may damage newly developing basal buds.

During the first spring grazing, the high quality of lucerne can increase the risk of red gut. Fibre sources such as palatable weeds (storksbill and shepherd's 
purse), straw and/or lignified portions of lucerne stems reduce this risk (Jagusch 1982).

For conserved crops, a height of 40-50 cm allows a compromise between maximising DM production and minimising the risk of lodging. This height is likely to occur before any flowers or buds have appeared on the stems (Figure 6). However, the complete removal of the lucerne canopy stimulates the development of new basal buds or promotes the extension of those already present by decreasing the ratio of red:far red light at the base of the plant. In conserved stands, the cutting height should be above the top of any developing basal buds. For grazed stands, stock should be removed before they damage these new shoots. Regrowth from the residual stems is of little importance in the regeneration of a new canopy after defoliation.

\section{Summer (December-February)}

From October until February, the objective is usually to utilise lucerne for grazing to maximise animal liveweight gain of priority stock. In the absence of water stress, lucerne growth and development are rapid, increasing in response to high temperatures and long photoperiods.

The number of crop regrowth cycles during this time is predominantly related to the availability of moisture. For example, three regrowth rotations gave a summer yield of over $7 \mathrm{tDM} /$ ha in dryland and irrigated crops (Brown et al. 2000; 2003) on a deep Wakanui silt loam soil with $350 \mathrm{~mm}$ of plant available water content (PAWC). In contrast, the crop at Ashley Dene on a very stony Lismore soil (PAWC $=150 \mathrm{~mm}$ ) yielded about $7 \mathrm{t} \mathrm{DM}$ /ha from three regrowth crops and most of this occured in the spring (Figure 5). Douglas (1986) provides an excellent summary of the comparative advantage of lucerne over pasture in different rainfall zones and for soils of different PAWC levels. Brown et al. (2003) recommended that lucerne should be planted on the deepest soils of a farm because it is the pasture species most able to utilise the water stored at depth.

Drought stress reduces DM production of crops, and the reduced transpiration from drought causes increased sward temperatures (Hattendorf et al. 1990; Varella 2002), accelerates phenological development (Varella 2002) and senescence (Irigoyen et al. 1992) and reduces quality (Peterson et al. 1992). Where crops have become drought stressed, they should be hard-grazed to avoid the loss of current production through senescence. Even a drought-stressed crop will slowly accumulate nodes on basal buds after such a defoliation, which enables a rapid response to any rainfall, but also means stock must be removed to protect these buds.

To maximise animal live-weight gain, finishing stock need to graze solely on lucerne, rather than intermittently on and off lucerne, for 6 to 8 weeks at an allowance of 2.5-4.0 kg DM/hd/d (Jagusch 1982). Stock selectively graze the highest quality top leaves and stem first, followed by the less palatable lower stem which may be left as the residual or grazed by dry stock (White \& Cosgrove 1990). Priority stock should be rotationally grazed for 7-10 days on a lucerne stand to remove this high quality forage and minimise the invasion of volunteer weeds from shorter grazing times (O’Connor \& Vartha 1968). Stock should then be moved to another lucerne paddock in a 4-5 paddock rotation. Residual stem can be grazed by dry or low priority stock, mown or left standing. Optimum grazing management during this time allows $35 \pm 4$ days regrowth (Douglas 1986).

Where lucerne can be irrigated, the optimum frequency and timing of water application is dependent on the available soil water-holding capacity (Hayman 1985). However, irrigation also encourages weed seed germination. After defoliation, the crop's demand for water is low. Therefore, irrigation should be delayed for 7-10 days to allow greater canopy development and light capture so that lucerne can outcompete germinating weeds.

\section{Autumn (March-May)}

The objective in autumn should change from stock performance to managing the stand for persistence and production in the following year. Decreasing temperatures and photoperiods at this time reduce both growth and development. During autumn, the main allocation of assimilates for the crop shifts from shoot to root production, replenishing reserves for overwintering and spring regrowth (Figure 2). To maximise root reserves, the crop should be allowed to reach $50 \%$ flowering in early-autumn (FebruaryMarch). This is because the thermal time required for flowering becomes progressively longer as photoperiod shortens in April and May (Figure 4).

For dryland crops, a lack of rainfall may not allow ideal management during autumn. Delaying the grazing of any autumn regrowth after significant rainfall will assist the plant in recovering reserves. 
This management technique has the added advantage of allowing the lucerne canopy to develop at a time when winter annual weeds are also germinating. The expanding lucerne canopy uses the rainfall at the expense of the initially shallower rooted weed seedlings. Thus, the ideal management for lucerne (and all pastures), after the rainfall that ends a prolonged summer dry period, is to spell the crop to maximise growth for the remainder of the season. Lucerne growth usually ends in a period of successive hard frosts in late autumn, which damage the vulnerable growing point at the top of the plant.

\section{ACKNOWLEDGEMENTS}

H.E. Brown received financial support for his $\mathrm{PhD}$ studies through the New Zealand Foundation for Research, Science and Technology. E. Teixeira received financial support for his $\mathrm{PhD}$ studies from the New Zealand Overseas Development Agency. Additional funding from Meat and Wool Innovations provided support for some of the fieldwork described in this study.

\section{REFERENCES}

Avice, J. C.; Ourry, A.; Lemaire, G.; Boucaud, J. 1996. Nitrogen and carbon flows estimated by $15 \mathrm{~N}$ and $13 \mathrm{C}$ pulse-chase labelling during regrowth of alfalfa. Plant Physiology 112: 281-290.

Brown, H. E.; Moot, D. J.; Pollock, K. M.; Inch, C. 2000. Dry matter production of irrigated chicory, lucerne and red clover in Canterbury. Proceedings of the New Zealand Agronomy Society 30: 129137.

Brown, H. E.; Moot, D. J.; Pollock, K. M. 2003. Long term growth rates and water extraction patterns of chicory, lucerne and red clover. In: Moot, D.J. (ed.) Legumes for dryland pastures. Proceedings of a New Zealand Grassland Assoication symposium, Lincoln University, 18-19 November 2003. Grasslands Research and Practice Series; no. 11: 89-97.

Christian, K. R. 1977. Effects of the environment on the growth of alfalfa. Advances in Agronomy 29: 183-227.

Douglas, J. A. 1986. The production and utilization of lucerne in New Zealand. Grass and Forage Science 41: 81-128.

Fick, G. W.; Holt, D. A.; Lugg, D. G. 1988. Environmental physiology and crop growth. pp. 163-194. In: Alfalfa and alfalfa improvement. Eds. Hanson, A.A; Barnes, D.K.; Hill, R.R. Jr. Madison, Wisconsin, USA.
Frame, J.; Charlton, J. F. L.; Laidlaw, A. S. Lucerne. 1998. Lucerne. pp. 107-179. In: Temperate forage legumes. CAB International: Wallingford, UK.

Hattendorf, M. J.; Evans, D. W.; Peaden, R. N. 1990. Canopy temperature and stomatal conductance of water-stressed dormant and nondormant alfalfa types. Agronomy Journal 82: 873-877.

Hayman, J. M. 1985. The effect of irrigation interval and soil type on pasture and lucerne production. Proceedings of the New Zealand Grassland Association 46: 15-23.

Heichel, G. H.; Delaney, R. H.; Cralle, H. T. 1988. Carbon assimilation, partitioning and utilization. pp. 195228. In: Alfalfa and alfalfa improvement. Eds. Hanson, A.A; Barnes, D.K.; Hill, R.R. Jr. Madison, Wisconsin, USA.

Hendershot, K. L.; Volenec, J. J. 1992. Taproot nitrogen accumulation and use in overwintering alfalfa (Medicago Sativa L.). Journal of Plant Physiology 141: 68-74.

Irigoyen, J. J.; Emerich, D. W.; Sanchez Diaz, M. 1992. Alfalfa leaf senescence induced by drought stress: Photosynthesis, hydrogen peroxide metabolism, lipid peroxidation and ethylene evolution. Physiologia Plantarum 84: 67-72.

Jagusch, K. T. 1982. Nutrition of ruminants grazing lucerne. pp. 73-78. In: Lucerne for the 80's. Agronomy Society of New Zealand Special Publication No. 1.

Kalu, B. A.; Fick, G. W. 1981. Quantifying morphological development of alfalfa for studies of herbage quality. Crop Science 21: 267-271.

Khaiti, M.; Lemaire, G. 1992. Dynamics of shoot and root growth of lucerne after seeding and after cutting. European Journal of Agronomy 1: 241247.

Kim, T. H.; Ourry, A.; Boucaud, J.; Lemaire, G. 1991. Changes in source-sink relationship for nitrogen during regrowth of lucerne (Medicago Sativa L.) following removal of shoots. Australian Journal of Plant Physiology 18: 593-602.

Kim, T. H.; Ourry, A.; Boucaud, J.; Lemaire, G. 1993. Partitioning of nitrogen derived from $\mathrm{N}_{2}$ fixation and reserves in nodulated Medicago Sativa L. During regrowth. Journal of Experimental Botany 44: 555-556.

Kirsopp, S. 2001. Management techniques to maximize legume production in dryland farming. Masters of Applied Science Thesis, Lincoln University.

Langer, R. H. M. 1967. The lucerne crop. A.H \& A.W Reed: Wellington, New Zealand. pp 314.

Major, D.; Hanna, M.; Beasley, B. 1991. Photoperiod response characteristics of alfalfa (Medicago 
Sativa). Canadian Journal of Plant Science 71: 87-93.

Moot, D.; Robertson, M.; Pollock, K. 2001. Validation of APSIM-Lucerne for phenological development in a cool-temperate climate. Proceedings of the 10th Australian Agronomy Conference.

O’Connor, K. F.; Vartha, E. W. 1968. Factors affecting weed incidence in lucerne. Proceedings of the New Zealand Weed and Pest Control Conference 21: 54-59.

Peterson, P. R.; Sheaffer, C. C.; Hall, M. H. 1992. Drought effects on perennial forage legume yield and quality. Agronomy Journal, 84: 774-779.

Purves, R. G.; Wynn-Williams, R. B. 1989. Lucerne - a fresh look. Proceedings of the New Zealand Agronomy Society 19: 95-102.

Rolston, M. P. 2003. Seed production issues that limit supplies or result in high market prices for dryland legume species. In: Moot, D.J. (ed.) Legumes for dryland pastures. Proceedings of a New Zealand Grasslands Association symposium, Lincoln University, 18-19 November 2003. Grasslands Research and Practice Series no. 11: 161-168.

Salinger, J. 2003. Climate reality - actual and expected. Legume options for dryland systems. Grasslands Research and Practice Series 11: 13-18.
Ta, T. C.; Macdowall, F. D. H.; Faris, M. A. 1990. Utilisation of carbon and nitrogen reserves of alfalfa roots in supporting $\mathrm{N}_{2}$ fixation and shoot regrowth. Plant and Soil 127: 231-236.

Thomas, R. 2003. Comparative growth forms of dryland legumes. In: Moot. D.J. (ed.) Legumes for dryland pastures. Proceedings of a New Zealand Grasslands Association symposium, Lincoln University, 18-19 November 2003. Grasslands Research and Practice Series no. 11: 19-25.

Varella, A. C. 2002. Lucerne crop responses to continuous and intermittent light under artificial and agroforestry regimes, Ph.D. Thesis, Lincoln University.

White, J. G. H. Lucerne grazing management for the 80's. pp 111-114. In: Lucerne for the 80's. Agronomy Society of New Zealand Special Publication No. 1.

White, J. G. H.; Cosgrove, G. P. 1990. Lucerne grazing management. 2. Effect of grazing duration on defoliation pattern by ewes. New Zealand Journal of Agricultural Research 33: 621-625.

Wynn-Williams, R. B. 1982. Lucerne establishment. Lucerne for the 80's. Agronomy Society of New Zealand Special Publication no. 11: 11-20. 